www.ijrap.net

\title{
A CLINICAL STUDY OF HARITAKYADIYOGA IN THE MANAGEMENT OF HYPER TRIGLYCERIDEMIA
}

Shah Deepti ${ }^{1 *}$, Saini Vinod ${ }^{2}$, Gautam Vishnu Prasad ${ }^{3}$, Mangal Gopesh ${ }^{4}$, Garg Gunjan $^{5}$

${ }^{1}$ Lecturer, Department of Kaya Chikitsa, S.S.M.D. Ayurveda College and Hospital, Moga, Punjab, India

${ }^{2}$ Lecturer, Department of Rasa Shastra and Bhaishajya Kalpana, S.S.M.D. Ayurveda College and Hospital, Moga, Punjab, India

${ }^{3}$ Reader, Department of Rasa Shastra and Bhaishajya Kalpana, MSM Institute of Ayurveda, BPSMV, Khanpur Kalan, Sonepat, Haryana, India

${ }^{4}$ Lecturer, P.G. Department of Panchakarma, N.I.A., Jaipur, Rajasthan, India

${ }^{5}$ Reader, Department of Swasthavritta, Shri Shiradi Sai Baba Ayurvedic College, Renwal, Jaipur, Rajasthan, India

Received on: 09/01/15 Revised on: 03/02/15 Accepted on: 27/02/15

*Corresponding author

Dr. Shah Deepti, Lecturer, Department of Kaya Chikitsa, S.S.M.D. Ayurveda College and Hospital, Moga, Punjab, India

E-mail: drdeeptishah82@gmail.com

DOI: $10.7897 / 2277-4343.06249$

\section{ABSTRACT}

The present clinical study was designed to study the hyper triglyceridemia associated with obesity and to see the response of Haritakyadi yoga. Hyper triglyceridemia is one of the major lifestyle disorders which have been referred to as the Santarpanjanya Vyadhi in the classical texts. There is in urgent need of natural strategies that are affordable and efficacious. The health care system known as Ayurveda has much to offer in this regards. A total number of 30 patients of hyper triglyceridemia disease were taken in the study and were given Haritakyadi yoga, 2 capsules twice a day for 2 month. Lipid profile test were done after 2 month of initiating treatment. After 2 month of therapy with Haritakyadi yoga, a reduction of serum triglycerides by $23.94 \%$ and also serum cholesterol by $5.95 \%$, serum LDL by $8.64 \%$ and serum VLDL by $8.65 \%$; serum HDL increased by $4.86 \%$ were noted. It was also found to have $19.38 \%$ effect on other objective parameters. The Haritakyadi yoga had better therapeutic compatibility in reduction of serum triglyceride value in patient of hyper triglyceridemia. Haritakyadi yoga was also found to have a significant effect on other subjective as well as objective parameters considered for the study.

Keywords: Hyper triglyceridemia, Haritakyadi yoga. Ayurveda

\section{INTRODUCTION}

Hyper triglyceridemia disease is a result of lifestyle factors such as over nutrition ${ }^{1}$. Which have been referred to as the Santarpanjanya Vyadhi in the classical texts ${ }^{2}$. Hyper triglyceridemia is defined as the presence of raised or abnormal level of triglyceride level in the blood $^{3}$. The raised levels of triglyceride have been identified as the primary modifiable risk factor in cerobrovascular disease ${ }^{4}$ and It's role has been appreciated in the manifestation of serious diseases like ischemic heart disease ${ }^{5}$, diabetes, stroke etc. Triglyceride are fat molecule that are composed of three long chain fatty acid attached to glycerol, fat cells accumulate triglyceride which are the body's primary source of stored energy. Hyper triglyceridemia can be divided into primary and secondary types. Primary triglyceridemia have genetic susceptibility, found in less than $5 \%$ of cases. Secondary triglyceridemia might have subtle inherited metabolic defect that confer susceptibility. Elevated plasma triglyceride concentration is a common biochemical finding, but the evidence for the benefit of treating this lipid disturbance remains less robust than that for treating elevated low-density lipoprotein-cholesterol. Part of the difficulty in the provision of specific recommendations has been the frequent coexistence of elevated triglycerides with other conditions that affect cardiovascular disease risk, such as depressed high-density lipoprotein, cholesterol, obesity, metabolic syndrome and type 2 diabetes.

\section{Aims and Objectives}

To study the role of Ayurvedic medicine Haritakyadi yoga in the management of hyper triglyceridemia in controlled clinical drug trial.

\section{MATERIAL AND METHODS Plan of study}

Hyper triglyceridemia was based on the presence of elevated triglyceride level was more than $150 \mathrm{mg} / \mathrm{dl}$ in lipid profile test according to NCEP ATP III guideline ${ }^{6}$; diagnosed patient irrespective of age, sex, religion, etc were registered form O.P.D. of kaya-chikitsa department of M.M.M. Govt. Ayurveda College, Udaipur, Rajasthan, India (Registration number: RAU/07/1525).

\section{Inclusion criteria}

Patients fulfilling the following general and diagnostic criteria were selected for the present study-

- Diagnosed Patients of Hyper triglyceridemia as per NCEP ATP III guideline.

- Patient of Hyper triglyceridemia with obesity, diabetes mellitus type-2, metabolic syndrome. 
- Body mass index (BMI) $<40$

\section{Exclusion criteria}

- Patient of primary hyper triglyceridemia.

- Patient's age more than 80 years and below 10 years.

- Patients having history of serious cardiac disorders like myocardial infarction, cardiac failure, etc.

- Patients having any major illness, insulin-dependent diabetes mellitus, diabetes mellitus that was poorly controlled.

- Hyperlipidemia due to drugs (e.g., glucocorticoids)

- Pregnant females and lactating mothers

- Renal insufficiency

\section{Study Design}

A total no. of 30 patient of hyper triglyceridemia were selected in the study and given Haritakyadi yoga.

Dose-500 mg 2 capsule twice a day (Drug extract 2 g/day),

Duration- two month,

Anupana- lukewarm water,

Kala- before meal,

Lipid profile test were done before treatment and after two month initializing treatment.

\section{Preparation of Haritakyadi yoga}

Ingredients of Haritakyadi yoga follows:

\begin{tabular}{|c|c|c|}
\hline Name & Latin Name & Part \\
\hline Haritki ${ }^{7}$ Extract & Terminalia chebula Retz. & 2 part \\
\hline Bibhitak $^{8}$ Extract & Terminalia Bellirica Roxb & 1 part \\
\hline Amalaki ${ }^{9}$ Extract & Embelica officinalis & 1 part \\
\hline Shunti ${ }^{10}$ Extract & Zingber officinale & 1 part \\
\hline Guduchi $^{11}$ Extract & Tinospora cordifolia & 1 part \\
\hline Nagarmotha ${ }^{12}$ Extract & Cyperus rotundus & 1 part \\
\hline Rasanjan ${ }^{13}$ Extract & Berberis aristata & 1 part \\
\hline Gomuttra Kshara ghan & Gomuttra Kshara & 1 part \\
\hline
\end{tabular}

\section{Pathya-Apathaya/ Dietary management}

All the registered patients were advice to follow specific dietary changes and exercises patterns.

\section{Assessment of therapy \\ Criteria of assessment}

During the trial the patient were assessed on the following biochemical assessment (complete lipid profile).

- Serum cholesterol (ch.)

- Serum triglyceride (Tg.)

- Serum high density lipoprotein (HDL)

- Serum low density lipoprotein (LDL)

- Serum very low density lipoprotein (VLDL)

- Body mass index (BMI) - the body mass index or Quetelet index, a measurement that compares a person weight and height, was also assessed.

\section{Statistical analysis}

The data was mainly analyzed using Student's unpaired t test and obtained results were interpreted as

\begin{tabular}{|c|c|}
\hline Insignificant & $\mathrm{P}<.05$ \\
\hline Significant & $\mathrm{P}<.01$ \\
\hline Highly significant & $\mathrm{P}<.001$ \\
\hline
\end{tabular}

The overall effect of the therapy was judged based on assessment of the lipid profile for which B.T. and A.T. was devised.

\section{Guideline for lipid profile}

According to National Cholesterol Education Program ATP III guideline

\section{OBSERVATION AND RESULT}

The study was conducted on 30 patients. Among the patients, $73.33 \%$ were in the age-group of 31-60 years; $56.67 \%$ were males, $86.67 \%$ were married, $76.67 \%$ were vegetarian, $83.33 \%$ were educated and $70 \%$ were Hindu by religion. The Prakriti Pariksha revealed that 30 $\%$ of the patients had kapha pradhan prikriti, $43.33 \%$ had vata kapha pradhan prikriti, 26.67 had pitta pradhan prikriti, $80 \%$ had tamasic prikriti, $50 \%$ were madhyama vyayama shakti and $50 \%$ were aver vyayama shakti, $53.33 \%$ were madhyama aahara shakti, $63.33 \%$ had madhyama satava, $50 \%$ of each madhyama and sthula sanghanan, $66.67 \%$ had madhyama pramana. The majority of the patient characterized by body weight 70 $85 \mathrm{Kg}, \mathrm{BMI}$ greater than $25 \mathrm{Kg} / \mathrm{m}^{2}$.

\section{Effect of therapy \\ Effect on symptoms}

Through the Haritakyadi yoga there was a relief of symptoms like chalasfig $(6.15 \%)$, chalodarsthan $(10.7$ $\%)$, javoprodha (21.9 \%), krachavyavayta (0 \%), nidradhikya (25.8\%), dorgandha (24.1\%), swedabadha $(12.5 \%)$, kshudhadhikya (19.4\%), pipasadhikya (19.6 $\%)$, shethilya $(11.4 \%)$, guruta $(17.8 \%)$, kshudra shvasa $(33.3 \%)$, shigdhagatrata $(30 \%)$ and vyayamasahatav $(38.8 \%)$. The relief of chalasfig, chalodarsthan, javoprodha, nidradhikya, dorgandha, swedabadha, shethilya, guruta, kshudra shvasa, shigdhagatrata, vyayamasahatav was statistically significant $(P<0.05)$, on kshudhadhikya, pipasadhikya the relief was highly significant $(\mathrm{P}<0.001)$ and krachavyavayta relief was non significant. Average relief in symptoms (objective parameter) was $19.38 \%$ in the patients.

\section{Effect on lipid profile}

On statistical evaluation by unpaired ' $t$ ' test Haritakyadi yoga was found to decrease serum triglyceride $(23.94 \%)$, serum cholesterol $(5.95 \%)$, increase H.D.L. (4.86 \%), decrease L.D.L. (8.68 \%) and V.L.D.L. (8.65 \%). 


\section{Overall effect of therapy}

In this drug trial 30 patients completed the full course of treatment. Statistical data mean improvement in treatment is as follows:
Weight $(\mathrm{Kg})$ 1.833333, BMI $\left(\mathrm{Kg} / \mathrm{m}^{2}\right)$ 0.863333, Serum Triglyceride 56.86, Serum Cholesterol 12.85, Serum HDL 1.94, Serum LDL 11.34, Serum VLDL 3.74 (Table 1)

Table 1: Statically analysis of therapy

\begin{tabular}{|c|c|c|c|c|c|c|c|c|}
\hline \multirow{2}{*}{ Object } & Mean & score & Mean difference & $\begin{array}{c}\text { \% } \\
\text { relief }\end{array}$ & S.D. & S.E. & $\begin{array}{c}\text { T } \\
\text { value }\end{array}$ & $\begin{array}{c}\text { P } \\
\text { value }\end{array}$ \\
\cline { 2 - 8 } & BT & AT & & 2.56 & 1.45 & 0.266 & 6.88 & $<0.001$ \\
\hline Weight $(\mathrm{kg})$ & 71.6 & 69.76 & 1.83 & 2.76 & 0.94 & 0.172 & 5.00 & $<0.001$ \\
\hline BMI $\left(\mathrm{kg} / \mathrm{m}^{2}\right)$ & 31.23 & 30.37 & 0.86 & 23.94 & 40.55 & 7.403 & 7.68 & $<0.001$ \\
\hline Triglyceride & 237.44 & 180.57 & 56.86 & 5.95 & 12.94 & 2.363 & 5.43 & $<0.001$ \\
\hline Cholesterol & 215.72 & 202.86 & 12.85 & -4.86 & 2.40 & 0.438 & -4.44 & $<0.001$ \\
\hline HDL & 40.033 & 41.98 & -1.94 & 8.68 & 11.32 & 2.102 & 5.39 & $<0.001$ \\
\hline LDL & 130.62 & 119.27 & 11.34 & 8.65 & 5.092 & 0.945 & 3.96 & $<0.001$ \\
\hline VLDL & 43.324 & 39.57 & 3.748 & & &
\end{tabular}

BT: Before Treatment, AT: After Treatment

\section{Adverse effect}

During the study no adverse event or effect was noted.

\section{DISCUSSION}

Thus, Haritkyadi yoga is a true formulation possessing pharmacological activity. All the patients followed strict dietary restrictions as well as lifestyle changes. The above findings are consistent with the Amapachana, Lekhna and upshoshana properties of the drug, which results in the reduction of symptoms in chalasfig, chalodarsthan, javoprodha, krachavyavayta, nidradhikya, dorgandha, swedabadha, shethilya, guruta, kshudra shvasa, shigdhagatrata, vyayamasahatav, kshudhadhikya and pipasadhikya. Serum triglycerides showed a better response to Haritakyadi yoga than serum cholesterol; the response however was not significant, which may be due to the fact that the stored triglyceride in our body is changed every 2-3 weeks due to its constant synthesis and utilization whereas it takes a longer duration to work on cholesterol. Haritakyadi yoga showed better results on other objective parameters related to obesity (i.e., body weight, BMI, body circumferences) which shows its depletory action on Sthayi Medo Dhatu. Thus, Haritakyadi yoga was seen to reduce the levels of bad cholesterol (serum LDL) and increase the levels of good cholesterol (serum VLDL); thereby correcting dyslipidemia. HDL is known to have protective action against atherosclerosis and to reduce the risk for cardiovascular disease. ${ }^{14}$

\section{Mode of action of Haritakyadi yoga}

The total effect of the Haritakyadi yoga is trodosha shamaka especially Kapha Vata Shamaka. It is katu in rasa thus it effect is Dipan, Pachan, Kapha shaman and Vatanuloman. It is Laghu, Ruksha and Tikshna in guna so it is Raktashodhak, Agnimandhar, Amahar, Nidrahar and Annadvashhar. Haritakyadi yoga is katu in vipaka and ushna in virya thus it's Agnidipak, pachan and vatanuloman. According to modern science-

- Amalaki, Shunthi, guduchi and mustak have hypocholesterolaemic effect. They may lower serum cholesterol, triglycerides, LDL and phospholipids without affecting HDL levels.

- Amalki, guduchi and Rasaut have hypoglycemic effect they may control the secretion of insulin.

- Triphala guduchi, mustak and rasaut have hepatoprotective effect. So they regulate metabolism in the body.

- So haritakyadi yoga is effective in hypertriglyceridemia due to hypocholestrolaemic, hypoglycaemic and hepatoprotective effect and also depan- pachan guna which reduces agnimandhya and amaotpatti and srotovarad.

\section{CONCLUSION}

Hyper triglyceridemia can be treated on the principal of agni samayakaran and apatarpana because hyper triglyceridemia arises due to medo-dusti. Haritakyadi yoga showed a better result on lipid profile (subjective parameters) as compared to objective parameters. Dietary and lifestyle changes are supportive to therapy in hyper triglyceridemia and obesity.

\section{ACKNOWLEDGEMENT}

Authors are grateful to the kaya-chikitsa department of M.M.M. Govt. Ayurveda College, Udaipur, Rajasthan, India for the support during the study.

\section{REFERENCES}

1. Mark B Andon and James W Anderson. State of the Art Reviews: The Oatmeal-Cholesterol Connection: 10 Years Later. American Journal of Lifestyle 2008; 2: 51-57. http://dx.doi.org/ $10.1177 / 1559827607309130$.

2. Sharma RK, Dash VB editors, Agnivesha, Charaka Samhita son Chakrapanidatta's 'Ayurveda Dipika', $7^{\text {th }}$ ed. Chowkhamba Sanskrit Series Varanasi: Sutra Sthana; 2002. p. 122.

3. http://en.wikipedia.org/wiki/Hyper triglyceridemia; 2009.

4. The world health report reducing risks, promoting healthy life. Geneva: world health organization; 2002.

5. Jacobson TA, Miller M, Schaefer EJ. Hyper triglyceridemia and cardiovascular risk reduction. Clinical Theory 2007; 29: 763-777. http://dx.doi.org/10.1016/j.clinthera.2007.05.002

6. Executive Summary of the Third Report of the National Cholesterol Education Program (NCEP) Expert Panel on Detection, Evaluation and Treatment of High Blood Cholesterol in Adults (Adult Treatment Panel III). Journal of the American Medical Association 2001; 285: 2486-2497. http://dx.doi.org /10.1001/jama.285.19.2486 
7. Sharma PV editor, Dravyaguna Vijnana Vol.2, $2^{\text {nd }}$ edition, Chowkhamba bharati academy, Varanasi; 1999. p. 753.

8. Sharma PV editor, Dravyaguna Vijnana Vol.2, $2^{\text {nd }}$ edition, Chowkhamba bharati academy, Varanasi; 1999. p. 239.

9. Sharma PV editor, Dravyaguna Vijnana Vol.2, $2^{\text {nd }}$ edition, Chowkhamba bharati academy, Varanasi; 1999. p. 758.

10. Sharma PV editor, Dravyaguna Vijnana Vol.2, $2^{\text {nd }}$ edition, Chowkhamba bharati academy, Varanasi; 1999. p. 331.

11. Sharma PV editor, Dravyaguna Vijnana Vol.2, $2^{\text {nd }}$ edition, Chowkhamba bharati academy, Varanasi; 1999. p. 761.

12. Sharma PV editor, Dravyaguna Vijnana Vol.2, $2^{\text {nd }}$ edition, Chowkhamba bharati academy, Varanasi; 1999. p. 370.

13. Sharma PV editor, Dravyaguna Vijnana Vol.2, $2^{\text {nd }}$ edition, Chowkhamba bharati academy, Varanasi; 1999. p. 539.
14. Rabbani Syed Arman, Ali Syed Mahtab. Unani drugs in the management of cardiovascular diseases: A review on pharmacological studies on Arjun and Zafran. Int. J. Res. Ayurveda Pharm 2013; 4(3): 463-467. http://dx.doi.org/ $10.7897 / 2277-4343.04332$

\section{Cite this article as:}

Shah Deepti, Saini Vinod, Gautam Vishnu Prasad, Mangal Gopesh, Garg Gunjan. A clinical study of haritakyadiyoga in the management of hyper triglyceridemia. Int. J. Res. Ayurveda Pharm. 2015;6(2):241-244 http://dx.doi.org/10.7897/2277-4343.06249

Source of support: Nil, Conflict of interest: None Declared 